\title{
Is a Presidential Item Veto Constitutional?
}

\author{
Paul R.Q. Wolfson
}

Congress' budget process is currently under attack. Critics charge that Congress is so unable to resist the influence of special interests and the concern with re-election that it loads appropriation bills with "porkbarrel" spending projects that are fiscally irresponsible and valuable to only a few. ${ }^{1}$ As a solution to the perceived congressional aversion to fiscal discipline, members of Congress, influential voices in the press, and President Reagan have suggested that Congress grant the President an "itemveto" power over appropriation bills. ${ }^{2}$ With this authority the President could veto wasteful parts of appropriation bills while consenting to the remainder.

The Constitution explicitly grants the President veto power only over bills; ${ }^{3}$ it is silent as to any such power over parts of bills. Due to the difficulty of amending the Constitution, members of Congress have introduced three types of legislation designed to create an item veto by statute. The "conventional" item veto would allow the President to veto directly parts of appropriation bills." The "impoundment" item veto would grant

1. See, e.g., Best, The Item Veto: Would the Founders Approve?, 14 PREs. STUD. Q. 183, 183 (1984); Dixon, The Case for the Line-Item Veto, 1 Notre Dame J.L. Ethics \& Pub. Pol'y 207, 211-17 (1985).

2. See, e.g., 131 Cong. Rec. S9873 (daily ed. July 23, 1985) (statement of Sen. Kennedy); Rescue the Senate!, Wall St. J., Feb. 26, 1985, at 34, col. 1 (editorial); 132 Cong. Rec. S1050 (daily ed. Feb. 5, 1986) (State of the Union message from President Reagan). Although the item veto probably had substantial support in the 99th Congress, see 131 CoNG. REC. $\$ 9878$ (daily ed. July 23, 1985) ( 57 of required 60 Senators voting for cloture resolution to break filibuster against item-veto bill), the resumption of Democratic control over the Senate has undoubtedly made passage of an item-veto bill less likely. See Budget Reform: A Red Herring for Red Ink, Wall St. J., Nov. 17, 1986, at 1, col. 5 (White House aide conceding that item veto "will 'never, never, never, never, never' pass Congress"); President Will Seek Alternatives to System of Budget Preparation, N.Y. Times, Nov. 14, 1986, at A1, col. 2 (item veto unlikely to gain needed congressional support). Not all of the item veto's supporters are conservative Republicans, however, see 131 Cong. REC. S9873 (daily ed. July 23, 1985) (remarks of Sen. Kennedy supporting item veto); nor are all of the item veto's opponents liberal Democrats. See 131 Cong. REC. S9939 (daily ed. July 24, 1985) (remarks of Sen. Hatch opposing item veto).

3.

Every Bill which shall have passed the House of Representatives and the Senate, shall, before it becomes a law, be presented to the President of the United States: If he approve he shall sign it, but if not he shall return it, with his Objections to that House in which it shall have originated, who shall ... proceed to reconsider it.

U.S. Const. art. I, $\$ 7$.

4. S. 1921, 98th Cong., 2d Sess. (1984), reprinted in Line-Item Veto: Hearings on S.J. Res. 26, S.J. Res. 178, and S. 1921 Before the Subcomm. on the Constitution of the Senate Comm. on the 
the President discretion to decide which funds to spend after he has signed an appropriation bill.5 A "rules" item veto would make the current presidential veto power more effective through new internal congressional procedures designed to partition appropriation bills into many separate bills for presentment to the President. ${ }^{6}$ Despite the substantial shift in power that any of these three measures would effect, neither supporters nor opponents of the item veto have attempted to develop the constitutional arguments in favor of and against the three types of bills. ${ }^{7}$

This Note will first assess a key argument of the item veto's supporters, that Congress' practice of enacting huge appropriation bills, often with nongermane riders, has encroached upon the presidential veto power and that the item veto is necessary to restore the constitutionally appropriate balance. It will show that this view is incorrect, that the nation's colonial and revolutionary constitutional arrangements as well as events during the framing of the Constitution demonstrate that the Framers were familiar with detailed and complex appropriation bills, including ones with riders. Moreover, because money bills passed by the lower houses of the colonial legislatures were unamendable by the upper houses or by the Grown, the Framers must have known that the President would be able to veto appropriation bills only with great difficulty. The Note will then argue that, given the intent of the Framers that the legislature should control government appropriations, the "conventional" and "impoundment" item vetoes would improperly delegate legislative power to the executive branch. Finally, in considering the "rules" item veto, it will show that, although Congress may have the power to enact such a mechanism, it must fail as a legal means of binding Congress to a regime of fiscal restraint, because either house could renounce the "rules" item veto at any time, without the consent of the other house or of the President.

Judiciary, 98th Cong., 2d Sess. 9-10 (1984) [hereinafter 1984 Hearing].

5. H.R. 4774, 98th Cong., 2d Sess. (1984).

6. S. 43,99 th Cong., 1st Sess. (1985), reprinted in Line Item Veto: Hearings on S. 43 Before the Senate Comm. on Rules and Administration, 99th Cong., 1st Sess. (1985) [hereinafter 1985 Hearings]. The terms "conventional," "impoundment," and "rules" used to describe the item-veto proposals are introduced in this Note.

7. By contrast, policy assessments of the item veto, i.e., inquiries as to whether the item veto would succeed in reducing the federal budget deficit, abound. See generally Symposium on the LineItem Veto, 1 Notre DAME J.L. ETHICs \& PUB. PoL'y 157 (1985). The line between policy analysis and constitutional analysis can blur, especially if the latter is reduced essentially to the question of whether the item veto would give the President too much power. Although this is an important question, the answer cannot definitively settle the issue of the constitutionality of the item veto if the answer that one gives depends on whether one thinks that Congress, or the President, currently exercises too much power. Asking whether a particular proposal would give "too much" or "too little" power will never yield the proper answer unless there is a point at which the distribution of power will be "just right." 


\section{The Item Veto as Threat to Legislative Power}

\section{A. The Historical Background of the Appropriation Power}

Supporters of the item veto argue that, whereas the Framers "intended to institutionalize the veto as part of the ordinary lawmaking process," Congress has encroached on the presidential veto power. Congress now shields questionable items from executive review by presenting huge appropriation bills to the President. This practice annuls the Framers' intention that the President could use the veto to turn aside unwise legislation, for he cannot exercise such a power at the cost of denying funds to the whole government. ${ }^{9}$ Because the President can veto only entire bills, Congress can also force the President to accept nongermane riders that probably would be vetoed if presented separately. ${ }^{10}$

The premise of the item veto's supporters, that the Framers were unaware of either omnibus appropriation bills or nongermane riders and would thus favor the item veto to redress the imbalance of power caused by these congressional incursions, is flawed. ${ }^{11}$ Both techniques are conso-

8. Best, supra note 1, at 187 ; see also 1984 Hearing, supra note 4, at 173 (statement of Secretary of Treasury Donald Regan); Ross \& Schwengel, An Item Veto for the President?, 12 PREs. Stud. Q. 66, 67 (1982). Contra R. LuCE, Legislative Problems 159 (1935) (before Presidency of Andrew Jackson, veto was used only to reject legislation that in President's opinion was unconstitutional or defectively drafted); Black, Some Thoughts on the Veto, LAW \& CoNTEMP. Pross., Spring 1976, at 87 (Framers probably intended such limited use of veto). The item veto's supporters argue that the Framers intended the veto to serve two purposes: to provide the President with a check against legislative usurpation of executive powers, and to force the reconsideration of possibly unwise laws. See The Federalist No. 51, at 322-23 (J. Madison) (C. Rossiter ed. 1961) (veto gives President power to resist legislative encroachment); THE Federalist No. 73, at 443 (A. Hamilton) (C. Rossiter ed. 1961) (veto furnishes "additional security against the enaction of improper laws"). A key assumption of the item veto's supporters is that the President's role in turning aside unwise legislation stems from his ability to represent the national interest in reviewing legislation as opposed to the tendency of members of Congress to respond to special and local interests and to accommodate these interests through log-rolling. See Givens, The Validity of a Separate Veto of Nongermane Riders to Legislation, 39 TEMP. L.Q. 60, 60-61 (1965); Ross \& Schwengel, supra, at 66-67; Shepsle, The Congressional Budget Process: Diagnosis, Prescription, Prognosis, in Congressional Budgeting 210 (W. Wander, F. Hebert \& G. Copeland eds. 1984).

9. 1984 Hearing, supra note 4, at 1-2 (statement of Sen. Hatch (quoting President Eisenhower)); id. at 42 (statement of Sen. Mattingly).

10. Givens, supra note 8 , at 62 . A fascinating twist on the rider occurred in the 99 th Congress when House Democrats tried to attach legislation to an appropriation bill that was certain to be vetoed in order to kill the legislation. The appropriation bill was an enormous supplemental measure, described by Representative Michel as a "great, bursting barrel of rancid pork," 132 CoNG. Rec. H1824 (daily ed. Apr. 15, 1986); the rider authorized aid to the Nicaraguan "contra" rebels. Id. The Democrats' attempt to join the two issues led to near-anarchy in the House. See 44 CoNG. Q. WEEKLY REP. 835 (1986).

11. See Best, supra note 1, at 187 (Framers unaware of such devices); Ross \& Schwengel, supra note 8, at 68 (same); Note, Separation of Powers: Congressional Riders and the Veto Power, 6 U. Mich. J.L. REF. 735, 738 (1973) (same). The University of Michigan Journal of Law Reform Note (which opposes a veto of nongermane riders) offers as the first congressional rider the amendment of the bill admitting Maine to statehood by a resolution to admit Missouri. Id. at 738 \& n.22. This demonstrates the difficulty of assessing the "validity" of riders. Although the merits of admitting the two states ought perhaps to have been considered separately, this early example of log-rolling was essential to the preservation of the union. Cf. R. LuCE, Legislative ProceduRe 548-49 (1922) 
nant with the Framers' understanding, informed by the colonial experience, that the executive should veto appropriation bills only with great difficulty. The absence of any special presidential veto power over spending measures proves not that the Framers were oblivious to the threat of legislative aggrandizement, but that they thought that congressional control over appropriations served as a crucial check against misgovernment by the executive. ${ }^{12}$ Most importantly, the Framers gave the President no power over the content of appropriation bills even though they knew that during the colonial period, the colonial assemblies' insistence that money bills were unamendable once they had passed the lower house had greatly facilitated the expansion of legislative power.

In the colonial era, British constitutional law required the consent of the House of Commons for the taxation of the kingdom. By the late seventeenth century, Commons had further established that it possessed the sole right to initiate tax legislation-to the exclusion of the House of Lords-and that tax bills passed by the Commons were unamendable in the Lords. The Lords could only accept or reject the revenue bills in toto. ${ }^{18}$ Nor could the king amend money bills; thus Commons in 1700 attached to a tax bill a rider annulling all the king's land grants in Ireland. Although the House of Lords resisted, William III agreed to the passage of the bill, including the rider, for the sake of obtaining the revenue. ${ }^{14}$

The lower houses of the colonial legislatures self-consciously imitated the British House of Commons in asserting their power of the purse. At an early stage the lower houses asserted the privilege of unamendability as well. ${ }^{15}$ This privilege proved to be a crucial constitutional advantage for

(discussing how law of ancient Rome prohibiting legislation containing unrelated subjects led to outbreak of civil war between Marius and Sulla after Senate rejected omnibus reform package as defective in form). Similarly, pork-barrel appropriation is largely in the eye of the beholder. See D. Stockman, The Triumph of Politics 150-51 (1986) (discussing disagreement between OMB Director Stockman and Sen. Schmitt over NASA appropriations). The classic example of pork barrel is the "water project," a large public works irrigation project usually located in the district of a powerful member of Congress. See id. at 148 (Red River Barge Canal protected by Sen. Long). But even water projects have their defenders. See, e.g., 125 Cong. REc. 18,915 (1979) (remarks of Sen. Hatfield) (arguing that "[t]hese are not so-called pork barrel projects. . . . [but] are capital investments in water resource development"); 123 CoNG. REc. 18,833 (1977) (remarks of Rep. Kemp) (seven water projects in his district "necessary to the economic and social well-being of the Buffalo area").

12. See The Federalist No. 58, at 359 (J. Madison) (C. Rossiter ed. 1961).

13. T. Taswell-Langmead, English Constrtutional. History 611 (10th ed. 1946).

14. See D. Ogg, England in the Reigns of James II and William III 451-52 (1955).

15. The lower house of the New York Assembly rejected amendments offered by the upper house as carly as 1711. J. Burns, Controversies BeTweEn Royal Governors AND THEIR ASSEMBLIES 306-07 (1923); see also J. GReEne, The QUest For Power: The Lower Houses of Assembly IN THE SOUTHERN ROYAL ColoniEs 1689-1776, at 66 (1963) (Virginia lower house rejected amendments in 1711); J. Pomfret, Colonial New Jersey 139 (1973) (New Jersey lower house rejected amendments in 1719). 
the colonial Commons in their struggles for power with the royal governors, especially for control of the colonial fisc. ${ }^{16}$

The British government at first maintained that the colonial legislatures had a role to play only in the taxing side of fiscal matters and that all spending decisions rested in the royal prerogative. ${ }^{17}$ But fearing the establishment of a foreign-born (British) bureaucracy at the expense of colonial tax money, ${ }^{18}$ the colonial legislatures learned that they could control disbursements as well as revenues by stipulating in tax bills the purposes for which the monies they granted would be used. ${ }^{19}$ As they customarily enacted taxing acts every year, they developed the practice of passing combined yearly taxing and spending measures for the support of the entire government. ${ }^{20}$

16. 6 Documents Relative to the Colonial History of the State of New-YoRk 764 (E. O'Callaghan ed. 1855) [hereinafter NEw YORK Documenrs] (letter from Gov. Clinton to Board of Trade complaining that unamendability gave lower house of New York Assembly "undue influence" over colonial government).

17. See J. GREENE, supra note 15, at 65-67.

18. See 6 NEw York Documents, supra note 16, at 554-56 (letter from Gov. Clinton to Board of Trade discussing popular suspicion that governor had converted tax revenues to private use; assembly's control over appropriations described as encroachment on royal prerogative).

19. The lower house of the Pennsylvania legislature claimed the right to control disbursements as early as 1694. J. Pole, Political Representation in England and the Origins of the AMERICAN REPUblic 88 (1966).

20. Unamendability also gave the colonial lower houses leverage against the British Privy Council, which exercised a reserve power to disallow colonial legislation beyond the governor's veto. The Privy Council exercised no item veto but always either approved legislation in full or disallowed it in full. See Flippin, The Royal Government in Virginia, 84 Colum. STUD. HIST. Econ. \& PUB. L. 1, 202 (1919). See generally Russell, The Review of American Colonial Legislation by the King in Council, 64 Colum. Stud. Hist. Econ. \& PuB. L. 421 (1915). Because the Privy Council could disallow a law at any time after its enactment, the British government sometimes allowed legislation with objectionable parts to operate for a time, during which period the governor could try to secure a repeal of the defects. If he could not, the Privy Council could then disallow the law. Id. at 474-76.

In 1760, the Board of Trade sought legal advice as to whether the British government could disallow parts of colonial legislation. 4 Acts of the Privy Council. of England, Colonial Series 440 (J. Munro ed. 1911); Russell, supra, at 626. The Privy Council had once, in 1680, disallowed one clause of a Virginia revenue act exempting ships built in Virginia or owned by Virginians from export duties on tobacco. 2 Acts of THE Privy Council of England, Colonial Series 11 (W. Grant \& J. Munro eds. 1910); Russell, supra, at 449. However this disallowance of 1680 took place under an early and unstable constitutional regime, in which the crown was trying to assume for itself the power to write and enact legislation, subject to the assent of the legislature. See L. LABAREE, ROYAL GovernMENT IN AMERICA 219-22 (1930). The crown's attempt to expand the royal prerogative to include the power to write colonial legislation failed primarily due to resistance from the colonial legislature of Jamaica, and the colonial constitution settled with legislative initiative in the assembly and power of assent in the crown.

That colonial legislatures took seriously their power to appropriate in detail is shown by the 1763 Georgia appropriation act, which provided $£ 1800$ for the support of the government during the year, including such accounts as $£ 12$ for a tree for the lighthouse, $£ 5$ for fire and candles for the General Assembly, \&2 for irons for Spanish prisoners, and $£ 110$ s $2 \mathrm{~d}$ for messenger services. Flippin, The Royal Government of Georgia: The Financial System and Administration, 1752-1776, 9 GA. HisT. Q. 187, 196 n.18 (1925); see also Bullock, The Finances of the United States from 1775 to 1789 , with Especial Reference to the Budget, 1 Bul.. U. Wis. Econ. Pol. ScI. \& Hist. Series 117, 216-19 (1895) (discussing colonial practice of appropriating in detail).

For an excellent discussion of one item of appropriation that was too objectionable to be accepted by a governor, namely a financial contribution by the legislature of South Carolina to the political cam- 
Unamendability meant that the colonial governors and upper houses had either to accept all the items of appropriation in the money bills or reject them all, risking confrontation with the lower house and denial of revenue. ${ }^{21}$ In fact, the lower houses did not hesitate to deny funding to the colonial governments on several occasions. ${ }^{22}$ Resistance by royal governors to the lower houses' control over disbursements proved ineffectual. ${ }^{23}$

Once the governors conceded the spending power to the legislatures, the lower houses used the power to control indirectly other powers previously presumed to lie within the royal prerogative. The South Carolina House of Commons was particularly aggressive in asserting control over the military by enacting appropriations so highly detailed as to curb most gubernatorial discretion. ${ }^{24}$ In many colonies the lower houses virtually usurped the appointment power by making appropriations for individuals rather than offices. ${ }^{25}$

Thus the colonial legislatures used unamendability to establish their right to judge the propriety of all expenditures ${ }^{28}$ and to curb executive power. They attempted to use unamendability to secure the passage of nongermane riders as well. Although royal governors had strict instructions not to assent to bills containing riders, ${ }^{27}$ the legislatures tried the device, and occasionally the colonial governments went without funding while the governor and representatives struggled for power. ${ }^{28}$

paign of John Wilkes, one of the greatest enemies of George III, see Greene, Bridge to Revolution: The Wilhes Fund Controversy in South Carolina, 1769-1775, 29 J. SouTHERN Hist. 19 (1963).

21. J. BuRNs, supra note 15 , at 103, 262-63, 300 .

22. See J. POMFret, supra note 15 , at 161 (New Jersey colonial officials not paid salaries for three years). Driven to distraction by intransigent assemblies, royal governors frequently had to dissolve colonial legislatures without a successful vote on appropriations. See, e.g., 6 NEw York DocuMENTs, supra note 16, at 282, 286-88 (letters from Gov. Clinton to Board of Trade discussing Assembly's unwillingness to appropriate for military expeditions); 1 THE Official RECORDS OF RoBert Dinwidde 303 (A. Brock ed. 1883) (Lieutenant Governor Dinwiddie chastising Virginia Assembly for failure to appropriate funds for French and Indian War).

23. So complete was the South Carolina House of Commons' victory that a 1750 instruction from the Board of Trade to the Governor of South Carolina ordering him to resist legislative attempts to appropriate went unheeded. J. GREENE, supra note 15 , at 89.

24. Id.

25. See, e.g., J. BuRNs, supra note 15, at 328 (New York).

26. For particularly eloquent expressions of this right by lower houses, see J. Grenne, supra note 15, at 407, and J. MAIN, The UPPER House in Revolutionary AMERICA 1763-1788, at 34 (1967); see also 6 NEw YoRK Documents, supra note 16, at 557 (letter from Gov. Clinton to Duke of Bedford) ("the King can not command a single farthing").

27. L. LABAREE, supra note 20, at 222.

28. In 1715 the Virginia House of Burgesses tacked on to a bill for the purchase of supplies for the defense of Carolina a provision repealing a much-disliked act authorizing government inspection of tobacco; the Governor vetoed the bill. T. WERTENBAKER, GIVE ME LIBERTY 167 (1958). The New York Assembly tried by means of a rider to a bill appropriating the salaries of judges in the colony to effect a major constitutional change: establishing that judges would hold office during good behavior and not at the King's pleasure. The upper house rejected the bill, and the judges were not paid. J. BuRNS, supra note 15, at 360-62; see 6 NEw YoRx DocumenTs, supra note 16, at 63; cf. 2 Records of the Federal Convention of 1787, at 273 (M. Farrand ed. 1937) [hereinafter M. FarRand] (Col. Mason discussing possibility that House would add nongermane riders to money 
During the Revolution, the supremacy of the lower houses in fiscal matters was codified in several state constitutions that denied the upper houses the right to amend money bills. ${ }^{28}$ This conviction that the people's direct representatives should control the purse had become so strong by the time of the Constitutional Convention that the delegates considered depriving the Senate of the right to amend tax or appropriation bills. ${ }^{30}$ The delegates at the Convention from the small states recognized, however, that establishing unamendability would give the House a crucial advantage over the Senate; thus they opposed unamendability as fatal to the balance between the two houses. ${ }^{31}$ Moreover, Madison argued to the Convention that unamendability would provoke conflict between the two houses and suggested that such had been the experience in the states that had adopted the principle. ${ }^{32}$

Even though the Convention gave the Senate an equal share in the power to write money legislation, thus establishing the Senate as a potential check on the misuse of money bills by the House, ${ }^{33}$ the Framers did nothing, besides giving the President the ordinary veto power, to establish the President as such a check on Congress. This omission is best understood in light of the long history of struggle between the colonial legislatures and governors over the content of spending bills. The Framers granted the President no special veto power over appropriation bills, yet they had experienced the confrontations between the branches of the colonial governments that had resulted from vetoes of spending measures, and they understood the advantage that power over spending had given the colonial lower houses. Indeed they restated the principle of legislative control over disbursements by insisting in the Constitution that "[n]o Money shall be drawn from the Treasury, but in Consequence of Appropriations made by Law."s4 That a presidential veto can be exercised over appropriation bills only with difficulty is consonant with the Framers' understanding that the ability of the people to force government to heed their wishes is most securely assured by the politically astute exercise of the fiscal powers by the legislature.

bills and suggesting that empowering Senate to amend them would defeat this practice).

29. See J. MaIN, supra note 26, at 107, 118, 129.

30. 2 M. FARRAND, supra note 28, at 273. Edmund Randolph wished to deny the Senate the power to amend money bills because he feared that the executive would have too much influence in the Senate. 2 id. at 279.

31. 13 The Documentary History of the Ratification of the Constitution 121 (J. Kaminski \& G. Saladino eds. 1981); see 2 M. FARRAND, supra note 28, at 210-11 (opposition of Maryland delegates); see also 1 id. at 527 (Madison remarking that "[i]f the Senate should yield to the obstinacy of the 1st. branch the use of that body as a check would be lost[;] [i]f the 1st. branch should yield to that of the Senate, the privilege would be nugatory").

32. 2 M. FARRAND, supra note 28 , at 224.

33. See supra notes $30-32$.

34. U.S. Const. art. I, § 9. 


\section{B. The Item Veto and the Nondelegation Doctrine}

\section{The Item Veto as Improper Delegation}

Political developments in the colonial period and during the framing of the Constitution established that Congress had authority over appropriations for the federal government. ${ }^{35} \mathrm{~A}$ transfer of authority to the President, through either the "conventional" item veto or the "impoundment" item veto, to decide which parts of appropriation bills to enforce, would be a delegation of Congress' spending power. ${ }^{36}$ Such a delegation, however, would be unconstitutional.

The principle of separation of powers prohibits Congress from abdicating its responsibility for primary policy-making in the federal government. ${ }^{37}$ Nonetheless, the delegation of legislative powers to executive and administrative agencies is essential to the modern administrative state. ${ }^{38}$

35. During the impoundment controversy of the 1970's, courts affirmed that power over spending lay with the legislative branch. See Campaign Clean Water, Inc. v. Train, 489 F.2d 492, 498 (4th Cir. 1973), vacated per curiam on other grounds, 420 U.S. 136 (1975); Louisiana ex rel. Guste v. Brinegar, 388 F. Supp. 1319 (D.D.C. 1975); Guadamuz v. Ash, 368 F. Supp. 1233 (D.D.C. 1973).

36. See J. Killian, Constitutionality of Empowering Item Veto by Legislation 15 (Congressional Research Service Jan. 4, 1984).

37. J.W. Hampton, Jr., \& Co. v. United States, 276 U.S. 394, 406 (1928) (describing delegation of legislative powers by Congress as "breach of the National fundamental law"); see Industrial Union Dep't, AFL-CIO v. American Petroleum Inst., 448 U.S. 607, 671-88 (1980) (Rehnquist, J., concurring in judgment) (arguing that Congress passed on to Secretary of Labor responsibility for deciding whether statistical probability of future deaths from exposure to chemicals outweighed economic costs of preventing those deaths).

38. See INS v. Chadha, 462 U.S. 919, 985-86 (1983) (White, J., dissenting); L. JAFFE, JudiciaL Control of Administratrve Action 33 (1965). The Supreme Court last struck down a federal law on grounds of undue delegation to the executive branch in A.L.A. Schechter Poultry Corp. v. United States, 295 U.S. 495 (1935). However, in National Cable TV Ass'n v. United States, 415 U.S. 336, 340 (1974), the Court suggested that Congress cannot delegate the power to levy taxes. Thus in FPC v. New England Power Co., 415 U.S. 345 (1974), a companion case to National Cable TV, the Court invalidated fees levied by the FPC in proportion to utilities' wholesale sales because such fees resembled taxes. The statute authorized administrative agencies to take into consideration the "public policy" served by the regulation as well as administrative convenience and cost of regulation in setting their fees. According to the Court, such valuation of public policy was a legislative function. The Court virtually wrote the "public policy" clause out of the statute.

Despite arguments that the delegation doctrine is essentially dead, its revival as a means of forcing legislatures to assume the task of making the hard policy decisions in a democracy has had remarkably broad support, from Chief Justice Rehnquist, see Industrial Union Dep't, AFL-CIO v. American Petroleum Inst., 448 U.S. at 671-88 (opinion concurring in judgment); on occasion from Justice Brennan, see California Bankers Ass'n v. Shultz, 416 U.S. 21, 91-93 (1974) (dissenting opinion); United States v. Robel, 389 U.S. 258, 269-77 (1967) (opinion concurring in result); but see FPC v. New England Power Co., 415 U.S. at 352-54 (Marshall, J., joined by Brennan, J., concurring in result) (arguing that delegation doctrine is as "moribund" as substantive due process); $c f$. McGautha v. California, 402 U.S. 183, 273-75 (1971) (dissenting opinion) (procedural safeguards more useful than articulated standards in ensuring that delegated power is exercised fairly by officials); from Justice Scalia, see Scalia, The Legislative Veto: A False Remedy for System Overload, REGulation, Nov./Dec. 1979, at 19, 23; from Judge Skelly Wright, see Wright, Beyond Discretionary Justice (Book Review), 81 Yale L.J. 575, 582-87 (1972); from John Hart Ely, see J. El.y, DemocracY AND DisTrust 133-34 (1980); and from Paul Gewirtz, see Gewirtz, The Courts, Congress, and Executive Poligy-Making: Notes on Three Doctrines, Law \& ContemP. Probs., Summer 1976, at 46, 49-65. The three-judge district court that held the Gramm-Rudman deficit-reduction law uncon- 
The Supreme Court has recognized that Congress frequently is unable to perform the entire function of legislating and must charge officials with some of its tasks. A field may be too technical ${ }^{39}$ or fast-changing ${ }^{40}$ for Congress to regulate directly; implementing a policy may require such attention to detail that if Congress were required to do everything, it would become so mired in specifics that it could not proceed to matters of general importance.11

Such transfers of authority assume that the delegate will further Congress' wishes in issuing regulations. ${ }^{42}$ They do not allow the delegate to review the propriety of congressional legislation and to terminate programs if, in the delegate's independent judgment, they seem unwise. ${ }^{43}$ Indeed, delegations of congressional power must be accompanied by "standards" or an "intelligible principle" to ensure that the delegate implements Gongress' will. ${ }^{44}$ Courts will insist that officials not use the

stitutional, see infra notes 52-54 and accompanying text, expressed the uncertain force of the delegation doctrine today when it noted that "the delegation doctrine remains valid law, but . . . its scope must be determined on the basis of the deferential post-Schechter cases decided by the Supreme Court." Synar v. United States, 626 F. Supp. 1374, 1384 (D.D.C.) (three-judge court) (per curiam) (dictum), affd on other grounds sub nom. Bowsher v. Synar, 106 S. Ct. 3181 (1986). In Bowsher v. Synar, the majority of the Supreme Court declined to reach the delegation issue. $106 \mathrm{~S}$. Ct. at 3193 n.10.

Although courts have rarely invalidated acts of Congress on grounds of excessive delegation, they have frequently held that agency actions taken pursuant to delegated authority were not in fact authorized by the statutes, especially when the actions intrude on fundamental rights. See, e.g., Lowe v. SEC, 472 U.S. 181, 207-11 (1985) (SEC not authorized to regulate newsletters offering investment advice to general public); Kent v. Dulles, 357 U.S. 116, 129 (1958) (Secretary of State not authorized to withhold passport because of citizens' political activities).

39. See Currin v. Wallace, 306 U.S. 1 (1939) (Secretary of Agriculture authorized to establish standards for grading tobacco); Union Bridge Co. v. United States, 204 U.S. 364 (1907) (Secretary of War authorized to determine whether bridges were unreasonable obstructions to navigation on na. tion's waterways).

40. See Permian Basin Area Rate Cases, 390 U.S. 747, 784 (1968) (agencies must be allowed to adapt rules to changing circumstances); National Broadcasting Co. v. United States, 319 U.S. 190, 219 (1943) (field of regulation, radio, was "new and dynamic").

41. See INS v. Chadha, 462 U.S. at 933 (intolerable system of private bills led Congress to delegate to Attorney General authority to suspend deportation in hardship cases); J.W. Hampton, Jr., \& Co. v. United States, 276 U.S. at 407 ("If Congress were to be required to fix every rate, it would be impossible to exercise the power at all.").

42. See Motor Vehicle Mfrs. Ass'n v. State Farm Mut. Auto. Ins. Co., 463 U.S. 29, 43 (1983) (agency rule arbitrary when it relies on factors that Congress did not intend it to consider).

43. Cf. id. at 58-59 (Rehnquist, J., concurring in part and dissenting in part) (agency did not act arbitrarily when it revoked regulation requiring passive restraints in automobiles because Congress had not explicitly required such restraints but had ordered agency to regulate under general "safety" standard; agency had not refused to enforce specific policy command by Congress but had acted under discretion granted in delegation statute).

44. The term "standards" was used by the Supreme Court in Yakus v. United States, 321 U.S. 414,423 (1944); "intelligible principle" is from J.W. Hampton, Jr., \& Co. v. United States, 276 U.S. at 409. In a few cases, the Supreme Court has upheld standardless delegations where the transfer of authority was to an entity possessing substantial inherent power in the regulated field. Delegation to the President of congressional authority touching foreign affairs is the classic example. See United States v. Gurtiss-Wright Export Corp., 299 U.S. 304 (1936). Similarly, the Court upheld a standardless delegation to Indian tribes of the power to regulate the sale of alcoholic beverages on reservations. United States v. Mazurie, 419 U.S. 544 (1975). The Court concluded that the tribes' independent 
delegated authority to pursue objectives different from those that Congress intended. ${ }^{45}$

The item veto presumes to ensure that Congress will be ineffective when appropriating extravagantly or for special interests. It would encourage the President to do exactly what courts ordinarily forbid him ${ }^{46}$ and other officials to do: alter or even nullify a congressional mandate. If Congress wishes to enlist the executive's assistance in reducing waste, it has a permissible method of so doing; it can budget in lump sums rather than line items and thus leave the executive to determine how funds within an account should be allocated. ${ }^{47}$ In lump-sum appropriations, Congress does not express a binding preference for specific programs by budgeting especially for them; the President and agencies are free to allocate monies as they think appropriate. ${ }^{48}$

In contrast, the item veto allows the President to disregard specific policy commands of Congress. The President could nullify not only items in appropriation acts but also programs previously enacted in substantive legislation that receive their funding through the regular appropriation process. The item veto would thus abrogate by legislation the President's

power over "internal and social relations of tribal life" was sufficient to justify a standardless delegation in that area, id. at 557, just as Congress may delegate to the states its power to regulate a field over which both Congress and the states possess regulatory authority. $C f$. Northeast Bancorp v. Board of Governors of the Fed. Reserve Sys., 472 U.S. 159, 168, 174 (1985) (Congress intended that state law govern permissibility of interstate bank acquisitions).

The appropriation power is not a field in which the President possesses independent authority. The Constitution requires that "[n]o Money shall be drawn from the Treasury, but in Consequence of Appropriations made by Law." U.S. Const. art. I, § 9; see E. Corwin, The Constiturion and What It Means Today 133 (14th ed. 1978) (clause "obviously addressed to the Executive"); see also Bowsher v. Synar, 106 S. Ct. 3181, 3208 (1986) (White, J., dissenting) ("[A]ppropriating funds is a peculiarly legislative function, and one expressly committed to Congress . . . ."). But see Letter from Attorney General Benjamin Civiletti to President Jimmy Carter (Jan. 16, 1981), reprinted in U.S. Gen. Accounting Office, Funding Gaps Jeopardize Federal Government OperaTIONS 76-92 (1981) (suggesting that President may have authority to appropriate funds to fulfill functions derived directly from Constitution, such as "the conduct of foreign relations essential to the national security," id. at 85 n.10).

45. See Hampton v. Mow Sun Wong, 426 U.S. 88, 114-16 (1976) (authorization to Civil Service Commission to "promote the efficiency of the Service" did not justify policy of excluding aliens from Service); FCC v. RCA Communications, 346 U.S. 86, 93-95 (1953) (FCC authority to regulate radio in "public interest" did not justify encouraging competition wherever possible).

46. Dissenting from the Court's holding in Panama Refining Co. v. Ryan, 293 U.S. 388 (1935), Justice Cardozo argued that article III courts could not review presidential actions with the same freedom that they possessed to review actions by officials. See id. at 447 . Nonetheless courts have invalidated Executive Orders for lack of conformity to standards set out in the delegating statute. See, e.g., Levy v. Urbach, 651 F.2d 1278 (9th Gir. 1981); Day v. United States, 611 F.2d 1122 (5th Gir. 1980).

47. UAW v. Donovan, 746 F.2d 855, 861 (D.C. Cir. 1984) (Scalia, J.), cert. denied, 106 S. Ct. 81 (1985).

48. UAW v. Donovan, 746 F.2d at 861; LTV Acrospace Corp., 55 Comp. Gen. 307, 318 (1975); see Train v. City of New York, 420 U.S. 35, 45 (1975) ("[L]egislative intention, without more, is not legislation."). 
constitutional duty to take care that the laws be faithfully executed; ${ }^{49}$ it would also reduce Congress from legislature to adviser.

\section{The Item Veto Contrasted with Permissible Delegations}

Although the Supreme Court's delegation cases are not easily harmonized, it is possible to discern three kinds of delegations that the Court has recognized as proper. The executive has enjoyed spending power corresponding to all three kinds. The impermissibility of the item veto is highlighted by contrast with these permissible delegations.

\section{a. Fact-Finding}

Congress can make the operation of a law contingent upon some future occurrence and charge the executive with the responsibility of deciding whether that event has taken place. ${ }^{30}$ This duty may require the exercise of substantial judgment; the delegate may, for example, have to evaluate complex economic factors in determining whether the relevant event has occurred. ${ }^{51}$

This delegation of fact-finding and fact-evaluating lay at the heart of the Gramm-Rudman deficit-reduction law. ${ }^{52}$ Presidential budget-cutting occurred when the Comptroller General determined, after assessing the likely revenues for the next year, that the budget deficit would exceed the amount permitted for that year. The Comptroller General was directed to use his judgment strictly in pursuance of Congress' policy; he could order cuts only if the deficit exceeded the level permitted by statute and only by the amount necessary to reduce the deficit to that level. ${ }^{\text {.s }}$ Congress had made the important decisions about the incidence and extent of budget reductions. ${ }^{54}$ This legislative direction, which the Gomptroller General

49. U.S. ConST. art. II, § 3.

50. Field v. Clark, 143 U.S. 649 (1892).

51. See Yakus v. United States, 321 U.S. 414, 424-25 (1944); Opp Cotton Mills v. Administrator, 312 U.S. 126, 144 (1941).

52. Public Debt Limit-Balanced Budget and Emergency Deficit Control Act of 1985, Pub. L. No. 99-177, 1985 U.S. Code Cong. \& AdmIN. News (99 Stat.) 1037 (codified in relevant part at 2 U.S.C. \$\$ 901-907 (Supp. III 1985)), held unconstitutional in part, Synar v. United States, 626 F. Supp. 1374 (D.D.C.) (three-judge court) (per curiam), affd sub nom. Bowsher v. Synar, 106 S. Ct. 3181 (1986). The district court opinion declaring Gramm-Rudman unconstitutional placed that delegation squarely in the line of "contingent legislation" cases. Synar v. United States, 626 F. Supp. at 1387 (dictum). But of. Kahn, Gramm-Rudman and the Capacity of Congress to Control the Future, 13 Hastings CoNsT. L.Q. 185, 196 n.44 (1986) (arguing that district court ignored or misunderstood crucial distinction between "real" contingencies such as economic conditions and contingencies that Congress itself creates, such as its failure to legislate).

53. 2 U.S.C. $\$ 901(a)(3)$, (c)(2)(B) (Supp. III 1985).

54. See Synar v. United States, 626 F. Supp. at 1389 (noting that "Comptroller General is not made responsible for a single policy judgment") (emphasis omitted); see also Bowsher v. Synar, $106 \mathrm{~S}$. Ct. at 3208 n.5 (White, J., dissenting) (embracing district court's analysis of delegation issues); id. at 3215 n.1 (Blackmun, J., dissenting) (same). 
had no power to disregard, contrasts sharply with the independent policy judgment that the President would exercise if the same objective of fiscal discipline were sought through an item veto.

\section{b. Subsidiary Policy-Making}

Congress frequently delegates to the executive the responsibility for making subsidiary policy decisions to effect Congress' general wishes in a particular field. This power to make subsidiary policy is a feature of the executive's authority to decide how funds within budget accounts should be spent."s5 Moreover, the use of lump sums rather than line items allows the executive to "reprogram" funds in an emergency without having to ask Congress for a formal reappropriation. ${ }^{58}$

Even when Congress has allowed the executive to "transfer" funds between budget accounts, it has done so under the assumption that such transfer authority would be used to save programs that would otherwise perish because Congress had appropriated too little or was unable to anticipate unforeseen developments. ${ }^{87}$ Such delegations do not amount to executive license to reorder congressional priorities by deciding that some programs are not worthy of funding. Rather they require the executive to use its discretion to preserve the congressional purpose.

55. See supra text accompanying notes $47-48$.

56. See Fisher, Reprogramming of Funds by the Defense Department, 36 J. PoL. 77, 78 (1974). "Reprogramming" of funds within budget accounts must be distinguished from "transfer" of funds between the accounts specifically set out in appropriation acts. Transfer is prohibited unless pursuant to congressional authorization. See id.

57. In 1809, after two decades of struggle between the Federalists and Republicans over the existence of what Hamilton claimed as an inherent executive power to transfer funds between budget accounts, Congress simultaneously authorized the President to transfer funds when it was out of session and when "necessary for the public service" and prohibited the President from transferring funds while it sat. By placing a restriction on presidential transfer authority, Congress rejected the claim of inherent presidential transfer authority. See L. Fisher, Presidential Spending Power 101-02 (1975).

Moreover, the political background of the 1809 settlement indicates quite clearly that the purpose of the discretionary grant was to allow the President the means to save programs, not to terminate them. During the first two decades Congress enacted appropriation acts with highly specific line items; in 1793, for example, the general appropriation act included such accounts as $\$ 34,856$ for forage for the War Department, $\$ 1500$ for the purchase of hydrometers, and $\$ 450$ for firewood, stationery, and printing in the Treasurer's office. See Act of Feb. 28, 1793, § 1, ch. 18, 1 Stat. 325, 327-28. That emphasis on detail was justified by one member of Congress as a safeguard against the possibility that the head of a department would apply lump-sum appropriations as he wished and not in respect of the policy preferences expressed by Congress-in short, a departmental item veto. See L. Wilmerding, The SPEnding Power 24 (1943). Constant executive over-spending in some accounts, or, from the other perspective, congressional mistakes in budgeting, led the executive to seek transfer authority so that departments would not have to cease operations during Congress' Iong absences from Washington if congressional appropriations proved insufficient. See generally id. ch. 2. The government's emphasis was always on the necessity of executive flexibility to save programs in the light of unforeseeable circumstances, particularly because of Congress' obsession with detailed appropriation acts. No commentator has suggested that Hamilton claimed transfer authority as a source of power to terminate congressional programs because the executive thought them unwise, or that Congress so intended the discretion that it gave to the executive. 


\section{c. Individual Cases}

Some delegations reflect the necessity of entrusting the executive with authority to make fact-specific decisions as to whether the enforcement of a law, in a particular case, is appropriate. Congress can empower the agency charged with the enforcement of a statute to grant mitigation or exemption from its operation. ${ }^{58}$ There is, of course, a danger that the executive will abuse this discretion, but Congress does not expect the executive to sabotage the statutory policy by refusing to enforce it at all.

Thus Congress has allowed agencies not to spend the full amount of funding granted in an appropriation act where savings are possible without a threat to the program's effectiveness, ${ }^{59}$ and it has permitted the President to defer obligations if disbursement at a later time within the authorized period will better serve the appropriation's purpose or save money. ${ }^{60}$ This limited power to withhold funding does not threaten the fundamentals of congressional policy. Congress understands that it budgets well in advance of the expected obligation of the funds and that estimates of agency needs may be faulty. ${ }^{61}$ This authorization to make savings at the margin does not empower the executive to "save" until the program becomes unenforceable. ${ }^{62}$ On the contrary, Congress assumes that the program will receive funding at some time and level that will ensure its effectiveness.

Developments also may arise that make disbursement of the funds contrary to the stated congressional purpose. During the impoundment con-

58. See INS v. Chadha, 462 U.S. 919, 933 (1983); The Laura, 114 U.S. 411 (1885).

59. See 31 U.S.C. $\$ 1512(c)(1)-(2)(1982)$ (Antideficiency Act) (current version); State Highway Comm'n v. Volpe, 479 F.2d 1099, 1118 (8th Cir. 1973) (previous version of Antideficiency Act did not permit executive to thwart congressional policy) (dictum); City of New Haven v. United States, 634 F. Supp. 1449, 1455 n.8 (D.D.C. 1986) (Congress intended revision of Antideficiency Act to prohibit its use as "instrument of policy-making").

60. Until recently, the President had the power to defer expenditure of appropriations under a provision of the Congressional Budget and Impoundment Control Act. See 2 U.S.C. § 684(a) (1982). The exercise of this deferral power was subject to a legislative veto. Id. $\S 684(b)$. The deferral authority was held inseverable from the unconstitutional legislative veto and invalidated in City of New Haven v. United States, 634 F. Supp. 1449 (D.D.C. 1986). The court accepted the plaintiffs' argument that the deferral power constituted a delegation, albeit a circumscribed one, of the legislative spending power. See id. at 1457; $c f$. R. Ehlke, Legal Analysis of Proposal to Repeal Deferral Authority under the Impoundment Control Act (Congressional Research Service Apr. 2, 1986) (arguing that Impoundment Control Act is not delegation of deferral authority but procedural mechanism for controlling deferral authority, which must stem from some other delegating act of Congress); Maine v. Goldschmidt, 494 F. Supp. 93, 98-99 (D. Me. 1980) (same).

61. See Fisher, supra note 56 , at 78 .

62. See Defendants' Supplemental Memorandum in Support of their Motion for Summary Judg. ment and in Opposition to Plaintiff' Motions for Summary Judgment at 9-11, City of New Haven v. United States, 634 F. Supp. 1449 (D.D.C. 1986) (No. 86-0455) (Department of Justice arguing that deferral authority is not like item veto because "the expenditure of the money is simply delayed"); $c f$. Note, Addressing the Resurgence of Presidential Budgetmaking Initiative: A Proposal to Reform the Impoundment Control Act of 1974, 63 TEx. L. REv. 693, 715 \& n.134 (1984) (discussing potential for executive manipulations of deferral authority to defeat programs' purposes). 
troversy, a court allowed HUD to suspend a housing subsidy program designed to give subsidies to the poor when the recipients were clearly middle-class. ${ }^{63}$ Yet even this rescission did not change Congress' priorities; rather, the court ratified an executive decision not to enforce a program once it became apparent that the program was not achieving the very purpose declared for it by Congress in the act itself.

\section{The Special Nature of the Spending Power}

The special nature of Congress' spending power and of the spending decisions that Congress must make further demonstrates the impropriety of the item veto. First, the exercise of all of Congress' other legislative powers depends for its effectiveness on funding; Congress must tax and spend to do anything. The appropriation process is really a means by which the legislature assigns priority among its programs. ${ }^{64} \mathrm{~A}$ transfer of spending power to the President would give him primary authority to set priorities for legislation. Second, as the Framers understood it, the legislature possessed the power of the purse as a guard against executive power. The spending power, as well as other congressional powers such as impeachment, is a legislative guard against executive misfeasance. ${ }^{65}$ The spending power is thus a "core" legislative power. ${ }^{68}$

Finally, the essence of all budgeting, not just pork-barrelling, is legislation for diverse interests. ${ }^{67}$ Apportioning the fisc requires hearing from interested recipients, assessing the validity of the conflicting demands, and coordinating all the programs in a compromise package. Only Congress can adequately balance these interests, for its size allows it to bring to policy-making a diversity of opinion, reflecting that of the members' con-

63. See Pennsylvania v. Lynn, 501 F.2d 848 (D.C. Cir. 1974).

64. See UAW v. Donovan, 746 F.2d 855, 862-63 (D.C. Cir. 1984), cert. denied, 106 S. Ct. 81 (1985).

65. For ratification-era characterizations of the power of the purse as a check on the executive, see 13 The Documentary History of the Ratification of the Constrtution, supra note 31, at 251 (Tench Coxe's essay on Presidency noting curb on presidential power in lack of control over fisc); The Federalist No. 58, at 359-60 (J. Madison) (C. Rossiter ed. 1961). For a recent telling example of the use of the spending power to curb executive misbehavior, see How to Get Attention, N.Y. Times, July 12, 1986, at 7, col. 2 (Sen. Weicker's introduction of provision cutting Attorney General Meese's travel budget prompted Justice Department to negotiate for improvement of Connecticut schools for retarded).

66. The district court invalidating Gramm-Rudman rejected this characterization of the spending power and suggested that there were no greater constitutional limits on delegation of the spending power than any other congressional power. Synar v. United States, 626 F. Supp. 1374, 1385 (D.D.C.) (three-judge court) (per curiam) (dictum), affd on other grounds sub nom. Bowsher v. Synar, $106 \mathrm{~S}$. C.. 3181 (1986).

67. It has not escaped commentators' attention that, possibly, what the people really want from budgeting is pork barrel. See, e.g., D. Stockman, supra note 11, at 390-94 (arguing that Reagan Revolution failed to bring about fiscal discipline because members of Congress correctly understood that United States had opted for appropriations based on governmental subsidies and largesse). 
stituents, that the President cannot have. ${ }^{68}$ In the presence of this diversity Congress can appreciate the trade-offs necessary in budgeting and make informed decisions about the national priorities. The item veto would deliver these decisions into the hands of only one policy-maker. Moreover, whereas the item veto's supporters claim a "national interest" perspective for the President, the President is no less likely than members of Congress to pursue partisan objectives, and his item veto may well exclude the interests of many voters whose opinions are better represented in Congress. ${ }^{69}$

\section{The "Rules" ItTem Veto}

A third item-veto proposal that has received considerable support in the Senate would avoid the delegation problems posed by the "impoundment" and "conventional" item vetoes but would achieve the desired close presidential review of appropriation measures through new internal congressional procedures for the passage of appropriation acts. After an appropriation bill passed both houses in the same form, the clerk of the house in which the bill originated would separate it into its component "items" and enroll each "item" as an individual bill for presentment to the President. The President would have no power to parse bills in their signing or enforcing; Congress would not be delegating any of its power over the appropriation process to the President because it would still be responsible for deciding the content of each item, and therefore of each resultant bill. If both houses so wished, they could still place nongermane riders or "logroll" appropriations within the items and thus have them enacted into law, ${ }^{70}$ but absent such a determined posture on the part of Congress, this

68. Madison defended against the Anti-Federalist attack that the House of Representatives was too small to be representative of the popular will by predicting rapid growth in the number of members of the House as the country's population increased. See THE FEDERALIST No. 55. Although Madison felt that the House need not be so large as to assure the members' familiarity with minutiae of the constituency's character, he conceded the importance of representing the nation's diverse interests in Congress and assured his readers that a ratio of 30,000 inhabitants to each representative would provide competent representation of local interests.

69. Opponents of the item veto have frequently urged that the use of the power will probably reflect partisan, not national, interests. See, e.g., Edwards, The Case Against the Line-Item Veto, 1 Notre Dame J.L. Ethics \& Pub. Pol'y 191, 193 (1985).

70. One of the "rules" item veto's supporters recognizes this as a possible source of weakness in the proposal. See J. Best, Objections to the Item Veto Considered, reprinted in S. REP. No. 92, 99th Cong., 1st Sess. 29 (1985) [hereinafter SENATE REPORT]; see also J. Killian, Constitutional Questions Raised by S. 43 in Establishing Item Veto, reprinted in SENATE REPORT, supra, at 18 (noting that Congress would retain control over composition of each item); SENATE REPORT, supra, at 32 (additional views of Sens. Dole, Warner, Garn) (same). The "rules" item-veto bill considered by Congress in 1985, S. 43, 99th Cong., 1st Sess. (1985), reprinted in 1985 Hearings, supra note 6, would define an "item" as any unnumbered section in an appropriation bill. But Congress has already demonstrated that it could easily evade such a definition of "item"; it passed an appropriation act in the form of one long unsectioned paragraph in 1793. See Act of Feb. 28, 1793, §1, ch. 18, 1 Stat. 325, 325-28. 
procedural or "rules" item veto would afford the President great influence over federal appropriations. ${ }^{71}$

The power to enact such drastic changes in congressional procedure rests in the constitutional authority of the houses to "determine the rules of [their] proceedings." ${ }^{172}$ Courts construing the rules clause have allowed the houses broad discretion, characterizing the houses' power over their procedures in expansive terms. ${ }^{73}$ But if the rules power gives to Congress the authority to promulgate the item veto, the plenary nature of the power also ensures that the "rules" item veto cannot impose effective institutional safeguards against budgetary indiscipline.

In exercising its rules power, a house can normally repeal or suspend its rules by one-house resolution, without the concurrence of the other house or the President. ${ }^{74}$ As proposed by the item veto's supporters, however, the "rules" item veto would be promulgated by statute. Because re-

71. 1985 Hearings, supra note 6, at 81-82 (statement of Louis Fisher) (noting that President could apply pressure on members of Congress with interests in particular items of appropriation).

72. U.S. ConST. art. I, $\S 5$; see J. Best, Objections to the Item Veto Considered, reprinted in SENATE REPORT, supra note 70, at 24 (suggesting rules clause as authority for establishing item veto). The House currently employs a procedural mechanism similar to the one proposed in $S$. 43 , see supra notes 6,70 , to avoid voting on bills to raise the ceiling on the national debt. Under the so-called "Gephardt rule," the House votes on the concurrent budget resolution (which is never presented to the President and never acquires the force of law); the part of the budget resolution containing the debt-ceiling measure is then detached from the rest of the resolution and "deemed" to have passed the House. Thus the House never considers a bill containing only the debt ceiling. 43 CoNG. $Q$. WeEkLY REP. 1788 (1985) (discussing Gephardt rule); see also 2 U.S.C. § 632(a)(5) (Supp. III 1985) (public debt to be part of concurrent budget resolution); 131 Cong. Rec. S135-36 (daily ed. Jan. 3, 1985) (statement of Sen. Mattingly) (relying on Gephardt rule to argue validity of S. 43).

In any case, the "enrolled bill" rule announced in Field v. Clark, 143 U.S. 649, 669-73 (1892), provides a conclusive presumption that a bill has passed both houses of Congress if the houses attest to that fact. This rule, based on "[t]he respect due to coequal and independent departments" by the judiciary, id. at 672, permits Congress to set its own methods for determining whether a bill has passed a house. See United States v. Ballin, 144 U.S. 1, 4-5 (1892) (rejecting challenge brought against revenue act as invalid on account of lack of quorum in House; House can freely set its rules for determining existence of quorum).

73. The first Supreme Court decision to consider the scope of the rules power was United States v. Ballin, 144 U.S. 1 (1892). The Court described the power thus:

[A]ll matters of method are open to the determination of the house, and it is no impeachment of the rule to say that some other way would be better, more accurate or even more just. It is no objection to the validity of a rule that a different one has been prescribed and in force for a length of time. The power to make rules is not one which once exercised is exhausted. It is a continuous power, always subject to be exercised by the house, and within the limitations suggested, absolute and beyond the challenge of any other body or tribunal.

Id. at 5 .

74. Research fails to disclose a single instance of enforcement of an internal rule of Congress by the executive branch through the courts. In United States v. Eilberg, 507 F. Supp. 267 (E.D. Pa. 1980), the government brought a civil suit against Representative Eilberg to recover the cost of personal telephone calls allegedly charged to the government. Eilberg moved to dismiss on the grounds that no statute, only a House rule, prohibited such acts. The government disagreed but conceded that "'[c]nforcement of a purely internal House rule by the executive and courts would be an encroachment on the powers of the House, a violation of the separation of powers, and a violation of the textual commitment clause [sic].' "Id. at 276 (quoting Reply to Memorandum Filed by the Clerk of the United States House of Representatives at 4). 
peal of a statute requires the concurrence of both houses and the President, ${ }^{75}$ the proponents of the "rules" item veto apparently view the procedures to be promulgated in the bill as binding on the houses until statutory repeal; ${ }^{78}$ neither house could alter its budget procedures on its own.

This Note argues that, just as either house may renounce procedures promulgated in internal rules by one-house resolution, so too may it abandon a procedure contained in a statute. The requirements of bicameralism and presentment do not apply to the repeal of congressional procedures. First, such statutory actions are not legislative acts; the houses are not governing the nation, but only themselves. Second, Congress cannot abridge the powers that the houses exercise independently of each other. Third, just as a legislature cannot alienate its legislative powers, neither should the houses be able to alienate the powers that they exercise ancillary to the process of lawmaking.

\section{A. The Rules Power as Distinct from Legislative Power}

Article I, section 7 requires the concurrence of both houses and the President before a bill can acquire the force of law. ${ }^{77}$ Not all of the houses' acts are legislative, however. What constitutes legislative activity is not easy to define, but the term certainly refers primarily to the promulgation of rules of conduct binding on the general public, not on members of Congress themselves. ${ }^{78}$ In INS v. Chadha, ${ }^{78}$ the Supreme Court recognized the distinction between self-governance and governance of others. The Chadha Court noted that whereas the houses of Congress have the power to set their own rules without each other's consent, ${ }^{80}$ the one-house legislative veto violated the bicameralism requirement because it was legis-

75. INS v. Chadha, 462 U.S. 919,954 (1983).

76. The "rules" item-veto bill considered by the Senate in 1985 included a two-year sunset clause; thus the proposal was "experimental" and could be abandoned after the trial period. Such a provision would be unnecessary if the procedures could be renounced at any time by either house. Moreover, the proposal is made not with sunset in mind but with the "clear intention of renewing and institutionalizing it if it passes the test of experience." J. Best, Objections to the Item Veto Considered, reprinted in SENATE REPORT, supra note 70, at 30.

77. See supra note 3.

78. Bowsher v. Synar, 106 S. Ct. 3181, 3194-204 (1986) (Stevens, J., concurring in judgment) (contrasting requirement that "when Congress . . . seeks to make policy that will bind the Nation, it must follow the procedures mandated by Article I," id. at 3194, with fact that "Members themselves necessarily engage in many activities that are merely ancillary to their primary responsibilities[;]. . . they make rules for the governance of their own business," id. at 3202-03).

79. 462 U.S. 919 (1983).

80. Id. at 956 n.21. Chief Justice Burger wrote for the Chadha Court that the houses' power over their internal rules empowers Congress to "bind itself." Id. It is not clear whether the Court was expressing an opinion that Congress could make its rules unrepealable, or whether it was using the term "bind" to refer to Congress' ability to set rules for itself, just as Congress "binds" the public when it enacts rules of general application. 
lative in character; it had "the purpose and effect of altering the legal rights, duties, and relations of persons . . . all outside the Legislative Branch." B1

The First Congress also recognized this distinction. ${ }^{82}$ In August 1789 the houses adopted joint rules establishing a method for the enrollment of bills for presentment to the President, ${ }^{83}$ but the Congress never presented these joint rules to the President for signature. A committee report of the Fifty-fourth Congress, considering this action of the First Congress in retrospect, noted that the First Congress did not consider presentment necessary because "the subject matter [of the joint rules] was not legislation per se." ${ }^{184}$ Congress could dispense with presidential approval, not because the procedures had been enacted as rules rather than statutes, but because their substance was not legislation. ${ }^{85}$ Because the substance of the "rules" item veto is a new procedure for considering and passing appropriation bills, neither its promulgation nor its repeal requires presentment to the President. $^{86}$

\section{B. The Rules, Power as Unabridgeable by Congress}

The rules power is one of several powers that the houses possess independently to make their legislative powers effective. The House of Representatives and the courts have long maintained that a house's power to exercise its ancillary functions cannot be abridged by a statute passed by both houses and signed by the President that attempts to channel or regulate those powers. When the Thirty-first Congress considered a law to provide for the taking of testimony in contested elections, members of the House were concerned that the statute might restrict each house's inde-

81. Id. at 952 (cmphasis added).

82. The Supreme Court has several times expressed the view that actions taken by the First Congress relating to specific parts of the Constitution are highly probative of the intent of the Framers. E.g., Bowsher v. Synar, 106 S. Ct. at 3187 \& n.3 (listing 20 members of First Congress who were also delegates at Constitutional Convention); Marsh v. Chambers, 463 U.S. 783, 790 (1983) (legislative chaplaincy does not violate establishment clause because First Congress appointed chaplain for itself); J.W. Hampton, Jr., \& Co. v. United States, 276 U.S. 394, 411-12 (1928) (Congress has power to lay import taxes for purpose of protecting domestic industry). But see Marbury v. Madison, 5 U.S. (1 Cranch) 137 (1803) (holding unconstitutional portion of Judiciary Act of 1789, passed by First Congress, because it increased original jurisdiction of Supreme Court beyond that expressly provided by Constitution).

83. The practice of promulgating procedures for the two houses by joint rules was common until 1876. See 5 A. Hinds, Precedents of the House of Representatives of the United States, H.R. Doc. No. 355, 59th Cong., 2d Sess. $\$ 6782$ (1907) [hereinafter A. Hinds]. Today the procedures for the enrollment of bills are set forth by statute. See 1 U.S.C. $\S 106$ (1982).

84. S. Rep. No. 135, 54th Cong., 2d Sess. 3 (1897).

85. See id. at 8.

86. See Kreeger Farms Home Dairy, Inc. v. Block, No. 85-5896, memorandum op. at 3 (D.C. Cir. Apr. 23, 1986) (President's signature unnecessary for portions of Congressional Budget Act affecting internal congressional procedures), cert. denied, $107 \mathrm{~S}$. Ct. 176 (1986). 
pendent power to judge its elections, so Congress expressly reserved to the houses the right to disregard the time limits set forth in the statute. Representative Strong, speaking in favor of the bill, assured the House that such a saving provision was not even necessary: "The right of the House [to judge its elections] . . . cannot be restricted [by law] and I do not propose that it should be restricted." on these remarks to disregard altogether the restrictions of the act. Representative Boyce of the Committee on Elections argued that "[b]y the Constitution, the House is made the judge of the elections, returns, and qualifications of its own members.' This power being granted by the Constitution is above all law, and cannot be taken away or impaired by any law." "88

Court constructions of other ancillary powers of the houses have established that Congress cannot abridge them by statute. The Supreme Court unanimously rejected the argument, made to attack a contempt conviction, that Congress "exhausted" the Senate's power to investigate the Teapot Dome scandal when the two houses by statute directed the President to do so. ${ }^{82}$ In a later case, the Eighth Circuit Court of Appeals put the principle yet more forcefully. A statute requiring that "all offices attached to the seat of government shall be exercised in the District of Columbia" did not preclude a Senator from holding a hearing in Lincoln, Nebraska, for "either house has the constitutional power to conduct separate investigations for proper purposes, and the Congress has no authority to limit the future exercise of that power."

Nor is a house's power to expel a member affected, constrained, or automatically triggered by the member's imprisonment for the commission of a federal crime.91 The power to expel members, not a legislative power but an ancillary one, remains available to each house alone, notwithstand-

87. Cong. Globe, 31st Cong., 2d Sess. 112 (1851). The Fifth Congress had enacted statutory procedures for the taking of testimony in contested elections. Members of the House had expressed doubts about the binding nature of the statute, arguing that the law was an application of the houses' powers over their own rules and elections, and that no house could abridge such powers of a later house. See 7 AnNals of Cong. 683-84 (1797). Representative Harper, of the committee that reported the bill, defended it as binding because it prescribed no internal rules but created a procedure outside the House binding "on the whole community." See 1 [Miscellaneous] American State Papers 160 (W. Lowrie \& W. Franklin eds. 1834); see also supra notes 79-85 and accompanying text (discussing distinction between regulation of internal congressional procedures and general regulation of society). By 1858, the House had abandoned this original internal/external distinction in favor of a broader view that the ancillary powers of the house, even those affecting outsiders such as the power to judge elections, could not be abridged by statute. See infra note 88 and accompanying text.

88. Cong. Globe, 35th Cong., 1st Sess. 725 (1858) (emphasis added) (quoting U.S. ConsT. art. I, § 5). Representative Boyce's view has become that of the House Parliamentarian, at least. See $1 \mathrm{~A}$. Hinds, supra note $83, \S 82$.

89. Sinclair v. United States, 279 U.S. 263, 295 (1929).

90. Seymour v. United States, 77 F.2d 577, 579 (8th Cir. 1935).

91. Burton v. United States, 202 U.S. 344 (1906). 
ing the houses' acting in concert to pass the criminal statute. A member in prison is a member until his house says otherwise; "[t]he seat into which he was originally inducted . . . could only become vacant . . . by some direct action on the part of the Senate in the exercise of its constitutional powers."

Similarly, the enactment of a criminal statute to punish contempt of Congress did not withdraw from the houses the power to punish contempt on their own.98 Although Congress could legislate to make contempt a criminal act, it did not follow that a citation by the House for contempt was a legislative act; if it were, then the concurrence of the Senate and the approval of the President would be necessary. The contempt power is "incidental to the legislative function," an "attribute of the power to legislate," and always retained by the houses. ${ }^{24}$ The rules power, like the contempt power, is ancillary to each house's exercise of legislative power and cannot be abridged by other entities.

\section{G. The Rules Power as Unabridgeable by Earlier Houses}

On some occasions when Congress has enacted procedural measures in statutes, it has expressly reserved to the houses the right to amend these rules. ${ }^{\text {gs }}$ Such saving clauses are not necessary. Even a single house acting alone cannot restrict the freedom of its successors to exercise its ancillary powers. The houses may not be limited in the exercise of the powers that the Constitution grants them..$^{28}$

Analogously, the Constitution vests the power of lawmaking in the two houses and the President; those three institutions are always free to exercise the legislative power, subject only to constitutional limits. Generally, a

92. Id. at 369 .

93. In re Chapman, 166 U.S. 661, 671-72 (1897). The power to hold witnesses in contempt is not a "general" power of Congress but is derivative of the powers of investigation and legislation. See Kilbourn v. Thompson, 103 U.S. 168, 197 (1881). Therefore, if the investigation being conducted does not concern a proper subject of legislation, the house has no power to cite for contempt a witness who refuses to cooperate. See Jurney v. MacCracken, 294 U.S. 125, 147-48 (1935); McGrain v. Daugherty, 273 U.S. 135, 173-74 (1927); cf. In re Cox Cotton Co., 24 Bankr. 930, 948 (Bankr. E.D. Ark. 1982) (courts have inherent power to hold parties in contempt but Congress does not).

94. McGrain v. Daugherty, 273 U.S. at 160-61, 173-74.

95. See, e.g., Metzenbaum v. FERC, 675 F.2d 1282, 1286 (D.C. Cir. 1982) (per curiam) (saving clause in Alaska Natural Gas Transportation Act); Krebs v. Ashbrook, 275 F. Supp. 111, 114 (D.D.C. 1967) (three-judge court) (relying on saving clause to decide that house rule contained in Legislative Reorganization Act of 1946 was not "Act of Congress" for purpose of convening threejudge court to hear constitutional challenges to acts of Congress, as required by jurisdictional statute); 123 Cong. REC. 36,309-11 (1977) (House suspending procedural provisions of Congressional Budget Act); 121 Cong. Rec. 7678-79 (1975) (same).

96. See Krecger Farms Home Dairy, Inc. v. Block, No. 85-5896, memorandum op. at 3 (D.C. Cir. Apr. 23, 1986) (court had "grave doubts" whether Congress through legislation could set rules for later Congresses that could be changed only through legislation), cert. denied, $107 \mathrm{~S}$. Ct. 176 (1986). 
legislature may not grant a party an interest in preventing the passage, amendment, or repeal of any law. ${ }^{97}$ The ban against making any law unrepealable finds expression in the maxim Salus populi suprema lex (The welfare of the people is the highest law). ${ }^{98}$ Salus populi suprema lex is not a statement of crude Utilitarianism; it is consonant with binding limits on the exercise of any power by the legislature, but only if those limits are placed by the people in a constitution and not imposed by the legislature itself. ${ }^{90}$

As the ban against unrepealability of statutes guarantees a legislature's full discretion to exercise its power to enact laws, so does a ban against unrepealability of procedures protect a house's discretion in its constitutional authority to set a legislative agenda, arrange for the manner of considering bills, and thus assign priority to the subjects before it. Adoption of the "rules" item veto would reflect a house's decision to defer substantially to the President's judgment in appropriation matters. Reversion to the current regime would be desirable when a house intended to assume greater responsibility for spending decisions, but if the "rules" item veto were binding on a house, it could not reassert its full authority in that area. The houses must be able to make decisions freely as to the relative importance of issues requiring legislation, for "the power to choose subjects for legislation is a fundamental attribute of legislative power."100

The ancillary powers guarantee the houses' effectiveness as institutions in the tripartite system of enacting laws; they may be "put on the [houses'] right to function." 101 To allow another branch or an earlier house to restrict the exercise of these powers would undermine their very

97. See Atkins v. Parker, 472 U.S. 115, 129-30 (1985) (no due process right to prevent Congress from adjusting AFDC benefit levels); Chase Securities Corp. v. Donaldson, 325 U.S. 304 (1945) (statute of limitations was matter of legislative grace, and its repeal did not deny due process to defendant in civil case); Reichelderfer v. Quinn, 287 U.S. 315 (1932) (Congress could alter by statute provisions for uses of park set forth in earlier statute); Beer Co. v. Massachusetts, 97 U.S. 25 (1878) (grant of charter to beer company did not prevent state from later prohibiting sale of alcohol); Rector of Christ Church v. County of Philadelphia, 65 U.S. (24 How.) 300 (1861) (church had no interest in continued enforcement of statute exempting it from taxation); Ohio Life Ins. \& Trust Co. v. Debolt, 57 U.S. (16 How.) 416 (1853) (charter granting insurance company exemption from taxation did not prevent state legislature from taxing it).

98. Beer Co. v. Massachusetts, 97 U.S. at 33. Montesquicu cited the maxim to support the prohibition against the unrepealability of any law. "When, by some Circumstance, the political Law becomes destructive to the State, we ought to decide by such a political law as will preserve it." $2 \mathrm{M}$. DE Montesquieu, Works 231 (London 1777).

99. Thus a state constitution could authorize the legislature to contract away the right to tax parties, and any subsequent attempt to tax them would be void. See Ohio Life Ins. \& Trust Co. v. Debolt, 57 U.S. (16 How.) at 428-30.

100. FERC v. Mississippi, 456 U.S. 742, 785 (1982) (O'Connor, J., concurring in judgment in part and dissenting in part).

101. Ex parte Daugherty, 299 F. 620, 625 (S.D. Ohio 1924) (describing contempt power), rev'd on other grounds sub nom. McGrain v. Daugherty, 273 U.S. 135 (1927). 
purpose. They stem directly from the Constitution and as such are above statutory abridgment and limited only by other constitutional provisions.

\section{CONCLUSION}

To instill fiscal discipline in the federal government, proponents of the item veto seek to restrict the effectiveness of Congress' spending power either directly or by constraining the discretion of the houses in their power over their own procedures. Such restrictions would undermine the effectiveness that the Framers understood as inhering in the legislature's appropriation power or would diminish the role that the houses play in lawmaking. Congress cannot constitutionally seek to solve its budget problems by attempting to divest itself of its constitutionally assigned powers. 